\title{
THE POLEMICS BETWEEN THE BUDDHISTS AND THE VAISHESHIKAS ON THE SELF IN "PUDGALAVINISHCHAYA" OF VASUBANDHU
}

\author{
L.I. Titlin \\ Institute of Philosophy RAS \\ Goncharnaya Str., 12 build. 1, Moscow, Russia, 109240
}

\begin{abstract}
The article examines the controversy between the "orthodox" Indian philosophical school Vaiśeșika and one of the greatest Buddhist philosophers - Vasubandhu (IV-V AD.) on the existence of subject ("ātman") as a reality. The discussion is investigated on the example of the text "Pudgalaviniścaya" (hereinafter PV). PV of Vasubandhu - literally "Study on the Self", or "pudgala" — is traditionally considered the $9^{\text {th }}$ chapter of "Abhidharmakośabhasya" of the same author and is one of the most important polemical treatises on the self, or ātman, in Buddhist philosophy. Among the issues discussed are the famous "epistemological argument", the ability of recall and perception, how a difference between moments of consciousness is possible, whether the substrate for consciousness is necessary. One of the strategies of Vasubandhu is that he tries to find internal contradictions in the arguments of opponents. We can say that the main argument of Vasubandhu is aimed at justifying the mechanism of the cause-and-effect occurrence of all phenomena (pratītya-samutpāda). If the Vaiśeșikas proceed from their logic about the need for a substance for qualities, then Vasubandhu tries to persuade them to his side and offer a fundamentally new explanatory model, according to which there are only sequence-like moments-phenomena (dharmas) that flow from each other according to the law of cause and effect.
\end{abstract}

Key words: ātman, anātman, "self", non-"self", Vasubandhu, Vaisheshika, consciousness, "Pudgalaviniscaya", "Abhidharmakosa-bhashya"

\section{INTRODUCTION}

Unlike traditional Western models of subject, which, as a rule, imply the existence of "Self", Buddhism (at least 2 thousand years before the first criticism of subject in the West) has put forward its original concept of "non-Self" (anātmavāda). The first similar criticism of the subject in the West has been proposed by D. Hume in his "Treatise on Human Nature", in which he introduced the so-called "bundle theory", according to which the Self is not a substantial and unique datum, but on the contrary, an aggregate or collection of "bundles" of certain fluctuating parts of consciousness, or phenomena.

This theory is very similar to the Buddhist doctrine of anātmavāda, which states that "Self" does not exist at the level of the ultimate reality while admiting its existence at the level of empirical truth as a conventional term to designate the so-called skandhas, or aggregates of dharmas.

Anātmavāda is a direct negation of "ātman" as a predicate, of the 5 aggregates that make up the psychophysical complex of a person called "skandhas", namely: [group of material] sensuality (rūpa), [group] of feelings ( vedanā), representations (samjñā), [group] of karmic factors (saṃskāra), [group] of perceptions (vijñāna). 
Although early Buddhism did not directly deny the existence of ātman (anātmavāda-1) and the Buddha preferred to answer the questions about its existence with "noble silence", in later Buddhism, which is at issue, Buddhists are directly talking about the actual nonexistence of ātman (ātma-nāsti, anātmavada-2).

It is important to note that the five aggregates (panchaskandha) do not merely constitute the subject, but also the non-dual subject-object adichotomia, the indivisible unity of the subject-object "life-world", i.e. they encompass not only the subject, but the whole knowable world, except for the so-called asamskrta dharmas (unconditioned dharmas, in particular, nirvāna). As the famous Russian Buddhologist Otton Rosenberg wrote in his work "The Problems of Buddhist Philosophy", «there is no sun, no person, but only a certain texture of correlates, elements-dharmas - sensual, conscious, mental, etc., which results in a single empirical illusory appearance called "a person seeing the sun"».

\section{"PUDGALAVINISCHAYA"}

We will discuss the main arguments of Buddhists against the theories of the substantial "self" with reference to Vasubandhu's (1) "Pudgalaviniścaya".

"Pudgalaviniścaya" (hereinafter - PV) - literally "Investigation of Self" or "pudgala" is one of the most important polemical treatises on self, or àtman, in Buddhist philosophy (2). Traditionally, the PV is considered to be the 9th book of Vasubandhu's "Abhidharmakośa-Bhāṣya" (AKB, "Encyclopedia of Buddhist Canonical Philosophy", IV-V AD).

AKB was translated into French [5] from Chinese, into English through French [6]. In Russian it is was translated completely, but it was translated from Sanskrit -6 books from 9: [7-9]. PV was translated into English three times: once from Tibetan [10] and twice from Sanskrit: [11] and [12]. Partially the translation from Sanskrit into Russian was published by us in the following articles: [13-15]. The full text of PV was translated into Russian in [16].

The core of the controversy in the treatise is directed against Pudgalavādins (so-called "heretical" school of Buddhism, which acknowledged the real existence of the so-called quasi-person, or pudgala as being not different and at the same time not identical with the aggregates, but "perceived on their basis") and Vaiśeșikas. Buddhists understood anātman (3) primarily as the denial of any constant principle in a person, a soul, as subject or agent. We will present the arguments of Vasubandhu against Vaiśeșikas as the easiest to understand.

\section{Introduction to "Pudgalavinishchaya"}

In the Introduction to PV Vasubandhu demonstrates the absolute impossibility of the existence of the self ("ātman") as a reality.

\section{The epistemological argument}

Vasubandhu opens PV with the question of whether there is an ātman? And he gives the answer: no, there is not. Further, he offers a genuine "epistemological argument", or "argument of imperceptibility". 
It boils down to this: "Self" (ātman) is not perceived either by any common sense organs, or during a special meditation, from which it is concluded that it does not exist.

For Buddhism the world does not extend itself beyond the experience of the world (i.e., the totality of all experienced objects), in other words, dharmas, or phenomena, have the status of ultimate reality. Vasubandhu recognizes two basic epistemological tools, by which in principle âtman could be known: the direct perception and the inference from effect to cause.

Direct perception, says Vasubandhu, is possible for seven of the twelve groups of dharmas (āyatanas), singled out in the cognition process. Only these seven âyatanas can act as "objects". These include: 1) visible, audible, objects of smell and taste, tangible, objects of manas, or mind (dharma-āyatana), and 2) manas itself.

Therefore, the logical inference from effect to cause is required only for the five remaining àyatana - five sensory organs, the necessary existence of which is proved by the fact of absence of sensory perception in the case of their non-functioning. By means of the immediate comprehension or logical inference, Vasubandhu says, we cannot apprehend anything other than the twelve āyatanas. Because àtman cannot be apprehended by any of the two epistemological tools, it cannot be attributed to dharmas, or elements of being. However, Vasubandhu does not completely deny ātman, or "self", but denies only its ultimate reality (dravya). He considers it just as a "name", a concept that is used in everyday human practice to refer to a constantly changing sequence of dharmas.

Therefore, ātman as a finite reality does not exist, and can only be considered as a conventional reality.

\section{Polemics with the Vaiśeșikas}

Vaiśeșika is an "orthodox" school of Indian philosophy, famous for its teaching about the categories of being and for the conception of the atomic structure of matter.

\section{Remembering and perception. How the difference of moments of consciousness can be possible?}

Question of the Vaiśeșikas (hereafter Vs.) 1. Vs. raise the question: how the recall and recognition of objects is possible, if there is no attman and "moments of consciousness" are momentary?

Answer of Vasubandhu (hereafter V.) 1. Vasubandhu says that, from the Buddhist point of view, there is a certain state of mind (bhavana-samskāra, mental imprint), which appears due to habit, repetition, etc., aimed at the recalled object and causally associated with it, preceding the act of remembering, which is not destroyed due to absent-mindedness, grief, etc. The remembering as a moment of consciousness causally arises from the preceding moment of consciousness.

Question of Vs. 2. Who, then, remembers, ask Vs., if there is no ātman? Vs understand the process of remembering on the basis of an "agent", which captures the object of perception using its recollection ability.

Answer of V. 1. V. asks whether there is any difference between the agent, grasping an object of recall, and the emergence of the recall in a stream of consciousness and 
says that there is none. What indeed causes recollection? As mentioned above, a special moment of consciousness. Although we say "Chaitra is perceiving", in fact we are just seeing the act of remembering in the stream called "Chaitra".

Question of Vs. 3. Who indeed owns recollection, if there is no ātman, ask Vs?

Answer of V. 1. V. retorts: what is meant by "ownership"? If the recall is directed to the object (in Vs terms), then it is not correct, because, firstly, the recall cannot move anywhere, secondly, it turns absurd, because a memory that is already there, is directed by subject to recall an object which already exists in memory. There is only one option - the "owner" of memory is the cause of its occurrence. This is what Vasubandhu himself argues. The relationship between "owner" and "ownership" is nothing more than a causal one.

Question of Vs. 4. Vs. ask: who is, in this case, the knower? Whose is the perception (vijñāna)?

Answer of V. 1. V. replies that simultaneous causes of such a consequence as a perception (vijñāna) are the presence of an object, as well as of an apprehending ability and attention.

Objection of Vs. 1. Vs. argue that all states refer to some substance. For example, the expression "Devadatta walks" or "Devadatta cognises" refer to a subject. (Predicates refer to subject). Therefore, there should be a subject of cognition.

The answer of V. 1. V. asks what is understood by a "subject Devadatta"? If it is attman as a substance, its existence is still to be proved. If it is a conventional 'self', it is indeed the opinion of the Buddhists. Moreover, the "walking" and "cognition" in fact are causal occurrence of some dharmas from other dharmas within the same stream.

It is not correct that perception "grasps" the object, in fact, but perception occurs causally in the form of an object. Vasubandhu admits that it can be conventionally said that some "agent" cognizes the object, for an actually preceding perception is the cause of the perception of an object, and in this sense it can be called its "agent". Perception is actually a sequence of causally interconnected "moments of consciousness", or perceptions.

Thesis of Vs. 1. Vs. object that if one moment of consciousness would have arisen from another one within the chain of causal dependence, rather than directly from àtman, in that case, either all the time the same moments of consciousness would appear, or different ones, but in the same predetermined sequence as e.g., the sprout appears from the seed, and the leaves from the sprout etc.

Counterargument of V. 1. V.: it is not the case, since consciousness consists of conditioned phenomena, and a defining characteristic of conditioned phenomena is impermanence.

Counterargument of V. 2. In addition, the established order is observable, however, it is not as strict as in the case with the sprout.

Thesis of V. 1. The same argument can be applied to the personalist philosophers (i.e., to the Vs) themselves who believe that consciousness arises from ātman in so much as they argue that atman and manas are eternal, it means that either all the time one and the same moment of consciousness will arise, or minds will always arise by the same pattern (as in the case of sprout). 
Counterargument of Vs. 1. Vs. also reply that this does not happen because attman is connected with manas in different ways (due to the so-called "specific connection").

Counterargument of V. 1. However, Vasubandhu again objects that since opponents consider both substances to be eternal (that is, unchangable), they can not unite differently, unless the "connection" is something third, different from them. And this is not proven.

Counterargument of V. 2. In addition, the definition of a connection involves the combination of things that were previously disconnected and located in different places. But according to the teachings of the Vs., attman is all-embracing and allpervasive and manas is always in the "field" of àtman.

Counterargument of V. 5. If Vs. say that the difference between states of minds is due to differences in perceptions (buddhi), V. objects: whence does the distinction of representations arise, if the connection between immutable ātman and manas is also immutable?

Counterargument of V. 6. If Vs. say that the difference of ideas results from the differences of impressions, or mental imprints, which influence the connected àtman and manas, Vasubandhu wonders whether there is any need to introduce âtman connected to manas, why would not be possible to explain the difference of cognitions by simple influence of different impressions on the manas?

A tman looks here out of place, it does not carry any semantic or functional load.

\section{CONCLUSION}

In Section 1 (Recollection and Perception: How is the Difference in the Moments of Consciousness Possible?) Vasubandhu tries to determine what is the cause of the various moments of consciousness (citta). Vaiśeșikas believe that it is ātman (soul), the task of Vasubandhu is to refute and justify the Buddhist concept of interdependent origin, in order to show that there is no ātman.

Thus, three problems are considered here 1) The problem of causality 2) The question of the existence of attman as a substance 3) The problem of the emergence of various moments of consciousness.

According to the Vaiśeșikas, consciousness is the quality (guna) of the derivative (kārya) from the atman as a substance (dravya). From their point of view, neither the body, nor manas or the indriyas have consciousness because of their instrumental nature, and also because of the need to obtain information about objects from outside, respectively, the only reason for the moments of consciousness can only be a atman.

The plant, given as an example in this passage, for the Vaiśeșikas represents a strict dependence of the effect on the cause, which is implicit in it. The consequence arises from the cause according to a clear and once-for-all established pattern, just as a plant emerges from a seed, and it, in turn, produces the fruit.

This example with a plant is used by both the Buddhists and the Vaiśeșikas to criticize each other's positions. Both those and others believe that within the theory of opponents, changes in the flow of moments of human consciousness are impossible. Thus, the Buddhists can not agree that attman can cause a variety of the individual's mental life, because it, according to the teachings of the majority of the Brahmanists, 
is an eternal, and therefore an unchangeable entity. Following the Buddhist logic, only a plant of a given species originates from the seed, so nothing can ever happen from the unchanging attman, for an immutable entity must not have the capacity for movement, generation. Vasubandhu believes that if attman was the cause of the emergence of various moments of consciousness, then, according to the law of cause and effect, from this moment of consciousness, either the same moment of consciousness or the quite predictable moment of consciousness according to a certain preestablished scheme, such as from a seed consistently develop a sprout, branches, leaves and the whole plant, which obviously contradicts our everyday experience.

If the Vaiśeșikas, trying to "save" the principle of eternal àtman, resort to manas, then to the sanskaras (mental impressions), then to the ideas (buddhi), then the Buddhists refer to the principle of anityatā (one of the three fundamental Characteristics of being), or the variability of all things and the doctrine of the cause-dependent origin (pratityasamutpāda). They believe that the investigation can not be predicted by a reason because of a multitude of contributing factors, or secondary causes (compare the Buddhist scheme of the hetu and pratyaya - causes and conditions). The same example with a plant, according to Buddhists, should be treated differently: the next phase in the development of a plant does not arise from the destruction of the previous one, for the non-being can no longer generate the being. On the contrary, the plant is considered as a sequence of dharmas (elements), in which each previous causally determines the next. We are dealing not with a simple scheme, the cause (seed) is a consequence (plant), but with the expanded one, in which each dharma, the moment of consciousness at every minute moment determines the moment of consciousness into the next, and only it - from the point of view of the Buddhists, the seed, in strict sense, is not the "cause" of the plant: in simplistic terms, the decomposition of the seed is the cause of its germination, germination is the cause of the germ, etc.

Section 2 (Is a Substrate Necessary for Consciousness?) Is devoted to the refutation of the concept of àtman as a substance in the doctrine of the Vaiśeșikas.

The term āśraya, which Vasubandhu uses here, can be understood in two ways: in the ordinary sense, as a physical basis, "support", and in the philosophical, in the sense of a "substratum" for qualities.

If we take a literal, material interpretation of the term āśraya, the question arises, of what ātman is the basis, or material "support"? After all, mental qualities are a priori immaterial, even according to the teachings of the Buddhists, they belong to the group of cetana ("mental qualities"). It is clear that material support is required only for material objects, in this sense it is recognized by the Buddhists also. But in what sense is it necessary for moments of consciousness? Âtman can not be the material basis of mental qualities, since it is not material and does not take place according to the teachings of the Vaiśeșikas, such is the verdict of Vasubandhu - they fall into an internal contradiction.

The Vaiśeșikas by the term "āśraya" try to introduce their theory that the âtman is a drayya (substance), and the mental states, respectively, are its qualities - gunas (the basis, the substrate). The doctrine of the substratum (āśraya, dravya) and qualities (guna) occupies an important place in the philosophy of the Vaiśeșikas. They interpret 
āśraya in the sense of a substratum of qualities, that is, as their unchanging foundation, "support" for the self-identity of any phenomenon whose qualities may well vary with time. As V.G. Lysenko points out, "dravya (the same as âśraya - L.T.) is defined as the basis of identity, i.e. the continuous existence of a thing as opposed to a changeable, discrete quality" [Lysenko, 2005, 488].

For Vasubandhu, such a position is fundamentally unacceptable. Recall that the Buddhists do not fundamentally distinguish between quality and its substance, which combine into a complex concept of dharma. Only dharmas, or ultimate elements of being, which number seventy-five, the Buddhists reckon to realities. Needless to say, there is no attman among them. All the other phenomena, except the ultimate ones, are considered conventional (dravya-siddha), that is, existing only at the level of empirical truth.

The five skandhas, or groups of dharmas - that's what we have according to Buddhism, there is no substratum behind them. In the final analysis, there are only realities, dharmas, no qualities exist. Thus, according to Vasubandhu, this argument of the Vaiśeșikas is āśraya-asiddha — - [error] of an unidentified substratum.

Summarizing this section, we can say that the main argument of Vasubandhu is aimed at justifying the mechanism of the cause-and-effect occurrence of all phenomena (pratītya-samutpāda). If the Vaiśeșikas proceed from their logic about the need for a substance for qualities, then Vasubandhu tries to persuade them to his side and offer a fundamentally new explanatory model, according to which there are only sequence-like moments-phenomena (dharmas) that flow from each other according to the law of cause and effect. Vasubandhu tries to disprove the relevance of the concept of substance-support, even for intangible phenomena, such as remembering and perception.

In the discussion with the Vaiśeșikas, Vasubandhu introduces many of those arguments, which will then be repeatedly used by Śantarakșita and Udayana (for example, if there was eternal ătman, all the moments of consciousness would take place simultaneously, since the eternal produces all its consequences simultaneously).

One of the strategies of Vasubandhu is that he tries to find internal contradictions in the arguments of opponents. However, here he often points to imaginary contradictions instead of existing ones, because he is guided by his own, Buddhist, logic. For example, he believes that the combination of two eternal substances, such as atman and manas, will inevitably lead to a change or even destruction of one of them, which is impossible. The internal logic of the Vaiśeșikas, on the other hand, says that the union of two eternal substances is entirely possible, if one of them is omnipresent (ātman), and the second one is not (manas). Here again, the main "problem" of the Buddhist-Brahmanist discussions is shown: both opponents are almost always guided by the logic of their system, instead of trying to understand the logic of the opposing side and find the internal contradictions in it. Because of this, the disputes between the Buddhists and the Brahmanists almost never have their resolution - they do not have losers or winners - each remains within its own system under the protection of its own special philosophical logic. 


\section{NOTES}

(1) For more on Vasubandhu, see V.K. Shokhin's article "Vasubandhu" [1. P. 203-207].

(2) For more information on the self in PV see publications: [2 - 4].

(3) In the future, all terms are recommended to look at the publications [17] and [18].

\section{REFERENCES}

[1] Filosofiya buddizma: Entsiklopediya [Philosophy of Buddhism: Encyclopedia]. Stepanyants MT. (Ed.). Moscow: Vosctochnaya Literatura, 2011 (In Russ).

[2] Titlin LI. "Anatman" (ne-Ya) kak klyuchevaya tsennostnaya ustanovka buddizma v kontekste ontologii vaibkhashiki i pudgalavady (na materiale 9-i knigi "Abkhidkharmakoshi" Vasubandkhu). ["Anatman" (non-Self) as the Key Value Setting of Buddhism in the Context of the Ontology of Vaibhashika and Pudgalavada (based on the 9th book of "Abhidharmakosha" of Vasubandhu)]. In: Idealy. Tsennosti. Normy: VI mezhdunarodnaya nauchnaya konferentsiya po vostokovedeniyu (Torchinovskie chteniya). [Ideals. Values. Norms: VI International Scholars' Conference on Oriental Studies (Torchinov Readings)]. 3-6 February 2010. Ed. SV Pahomov. St.-Peterburg; 2010. p. 216-221. (In Russ).

[3] Titlin LI. Ponyatie sub" "ekta v buddizme pudgalavady. [The Notion of Subject in Pudgalavada Buddhism]. Istoriya Filosofii [History of Philosophy] 2013: (17):15-40. (In Russ).

[4] Titlin LI. Problema ontologicheskogo statusa sub"ekta v "Pudgala-Vinishchae" Vasubandkhu. [The Problem of Ontological Status of Subject in "Pugdala-vinishcaya" of Vasubandhu]. Psihologiya i Psihotekhnika [Psychology and Psychotechnics] 2011; (8). Moscow: Nota Bene, p. 91-102. (In Russ).

[5] L'Abhidharmakosa de Vasubandhu. Traduit et annoté par L. de la Vallée Poussin. Chap. 1-9. Paris: P. Geuthner, 1923-1931.

[6] Vasubandhu. Abhidharmakosabhasyam. Translated by Louis de La Vallée Poussin; English translation by Leo M. Pruden. Berkeley, Calif., 1998-1990.

[7] Enciklopediya Abhidharmy (Abhidharmakosha). T. 2: Razdel III: Uchenie o mire; Razdel IV: Uchenie o karme [Encyclopedia of Abhidharma (Abhidharmakosha). V. 2: Section III: The Doctrine of the World; Section IV: The Doctrine of Karma]. Izd. podgot. EP Ostrovskaya, VI Rudoj. Moscow: Ladomir; 2001. (In Russ).

[8] Enciklopediya Abhidharmy (Abhidharmakosha). T. 1: Razdel I: Uchenie o klassah ehlementov; Razdel II: Uchenie o faktorah dominirovaniya v psihike [Encyclopedia of Abhidharma (Abhidharmakosha). [V. 1: Section I: Teaching about the Classes of Elements; Section II: Teaching about the Factors of Domination in the Psyche]. Izd. podgot. EP Ostrovskaya, VI Rudoj. Moscow: Ladomir; 1998. (In Russ).

[9] Enciklopediya buddijskoj kanonicheskoj filosofii (Abhidharmakosha). Razdel V - Uchenie ob affektah. Razdel VI - Uchenie o puti blagorodnoj lichnosti [Encyclopedia of Buddhist Canonical Philosophy (Abhidharmakosha). Section V - Teaching about affects. Section VI. The Doctrine of the Way of the Noble Person]. Sostavlenie, perevod, kommentarii, issledovanie EP Ostrovskoj, VI Rudogo. St.-Peterburg: Izd-vo S.-Peterb. Un-t; 2006. (In Russ).

[10] Stcherbatsky T. The Soul Theory of the Buddhists. Delhi: Bharatiya Vidya Prakashan; 1976.

[11] Kapstein M. Reason's Traces: Identity and Interpretation in Indian and Tibetan Buddhist Thought. Boston: Wisdom Publications; 2001.

[12] Duerlinger J. Indian Buddhist Theories of Persons. Vasubandhu's Refutation of the Theory of a Self. Taylor and Francis e-Library; 2005.

[13] Titlin LI. Polemika Vasubandkhu so storonnikami ucheniya o pudgale (individe) v "Pudgalavinishchae" c prilozheniem "Pudgala-vinishchaya" Vasubandkhu s kommentariem "Spkhutartkha" Yashomitry (fragment). [Polemics of Vasubandhu with Supporters of the Pudgala (Individual) Teaching in Pudgala-vinishchaya with an Excerpt of "Pudgala-vinishchaya" of Vasubandhu with the commentary "Sphuthartha" of Yashomitra]. Istoriko-filosofskij ezhegodnik 2013. [Historical and Philosophical Yearbook]. Moscow: Kanon+, 2014. P. 256-276. (In Russ). 
[14] Titlin LI. Vasubandkhu. "Pudgalavinishchaya". Predislovie, Per. Fragmentov 943—948. [Vasubandhu. Pudgalavinishchaya. Foreword, Trans. of Excerpts 943-948]. Vestnik Rossiiskogo universiteta druzhby narodov. Seriya "Filosofiya". [Bulletin of the Russian University of Peoples' Friendship. Series: Philosophy"]. 2016; (4):116-128. (In Russ).

[15] Vasubandkhu. "Pudgala-vinishchaya". Predislovie, per. Fragmenta, primech. L.I. Titlina [Vasubandhu. Pudgala-vinischaya (Preface, Translation of an Excerpt, Notes by L.I. Titlin)]. Istoriya filosofii. 2015;20(2):107-125.

[16] Titlin L. Problema subyekta v indiyskoy filosofii ("Pudgalavnishchaya" Vasubandkhu). [The Problem of Self in Indian Philosophy ("Pudgalavinscaya" of Vasubandhu")]. Moscow: Ontoprint; 2018.

[17] Filosofiya buddizma: Entsiklopediya [Philosophy of Buddhism: Encyclopedia]. Stepanyants MT. (Ed.). Moscow: Vosctochnaya Literatura; 2011 (In Russ).

[18] Indiiskaya filosofiya: Entsiklopediya [Indian Philosophy: Encyclopedia]. Stepanyants MT. (Ed.). Moscow: Vosctochnaya Literatura; 2009. (In Russ).

DOI: 10.22363/2313-2302-2019-23-1-46-55

\title{
ПОЛЕМИКА О СУБЪЕКТЕ МЕЖДУ БУДДИСТАМИ И ВАЙШЕШИКАМИ В «ПУДГАЛАВИНИШЧАЕ» ВАСУБАНДХУ
}

\author{
Л.И. Титлин \\ Институт философии РАН \\ ул. Гончарная, д. 12, стр. 1, Москва, Россия, 109240
}

В статье рассматривается полемика между «ортодоксальной» индийской философской школой вайшешика и одним из величайших буддийских философов - Васубандху (IV-V вв.) о существовании субъекта («атмана») как реалии. Дискуссия исследуется на примере текста «Пудгалавинишчаи» Васубандху (далее - ПВ). ПВ - буквально «Исследование субъекта», или «пудгалы» - традиционно считается 9-й главой «Абхидхармакоша-бхашьи» того же автора и является одним из наиболее важных полемических трактатов о субъекте, или атмане, в буддийской философии. Среди обсуждаемых вопросов - знаменитый «гносеологический аргумент», способность вспоминать и воспринимать, как возможна разница между моментами сознания, необходим ли субстрат для сознания. Одна из стратегий Васубандху заключается в том, что он пытается найти внутренние противоречия в аргументах оппонентов. Можно сказать, что главный аргумент Васубандху направлен на обоснование механизма причинно-следственного возникновения всех явлений (пратитьясамутпада). Если вайшеники исходят из собственной логики о необходимости субстанции для качеств, то Васубандху пытается убедить перевести их на свою сторону и предлагает принципиально новую объяснительную модель, согласно которой существуют только последовательности моментов-явлений (дхарм), которые возникают друг за другом в соответствии с законом причины и следствия.

Ключевые слова: атман, анатман, «я», не-«я», Васубандху, вайшешика, сознание, «Пудгалавинишчая», «Абхидхармакоша-бхашья»

\section{ЛИТЕРАТУРА}

[1] Философия буддизма: энциклопедия / отв. ред. М.Т. Степанянц; Ин-т философии РАН. М.: Вост. лит., 2011. 1050 с.

[2] Титлин Л.И. «Анатман» (не-Я) как ключевая ценностная установка буддизма в контексте онтологии вайбхашики и пудгалавады (на материале 9-й книги «Абхидхармакоши» Васубандху) // Идеалы. Ценности. Нормы: VI международная научная конференция по востоковедению (Торчиновские чтения). 3-6 февраля 2010 г. / сост. и отв. ред. С.В. Пахомов. С.-Петербург: Изд-во СпбГУ, 2010. С. 216-221. 
[3] Титлин Л.И. Понятие субъекта в буддизме пудгалавады // История философии № 17. М.: Изд-во ИФ РАН, 2013. С. 15-40.

[4] Титлин Л.И. Проблема онтологического статуса субъекта в «Пудгалавинишчае» Васубандху // Психология и Психотехника. 2011. № 8. М.: Nota Bene, 2011. С. 91-102.

[5] L'Abhidharmakosa de Vasubandhu. Traduit et annoté par L. de la Vallée Poussin. Chap. 1 - 9. Paris: P. Geuthner, 1923-1931.

[6] Abhidharmakosabhasyam. Translated by Louis de La Vallée Poussin; English translation by Leo M. Pruden. Berkeley, Calif., 1998-1990.

[7] Васубандху. Энциклопедия Абхидхармы (Абхидхармакоша). Т. 2: Раздел III: Учение о мире; Раздел IV: Учение о карме. Изд. подгот. Е.П. Островская, В.И. Рудой. М.: Ладомир, 2001. $670 \mathrm{c.}$

[8] Васубандху. Энциклопедия буддийской канонической философии (Абхидхармакоша). Раздел V: Учение об аффектах. Раздел VI: Учение о пути благородной личности / составление, перевод, комментарии, исследование Е.П. Островской, В.И. Рудого. СПб.: Изд-во С.-Петерб. ун-та, 2006. 524 с.

[9] Васубандху. Энциклопедия Абхидхармы (Абхидхармакоша). T. 1. Раздел I: Учение о классах элементов; Раздел II: Учение о факторах доминирования в психике / изд. подгот. Е.П. Островская, В.И. Рудой. М.: Ладомир, 1998. 670 с.

[10] Stcherbatsky T. The Soul Theory of the Buddhists. Delhi: Bharatiya Vidya Prakashan, 1976.

[11] Kapstein M. Reason's Traces: Identity and Interpretation in Indian and Tibetan Buddhist Thought. Boston: Wisdom Publications, 2001.

[12] Duerlinger J. Indian Buddhist Theories of Persons. Vasubandhu's Refutation of the Theory of a Self. Taylor and Francis e-Library, 2005.

[13] Титлин Л.И. Полемика Васубандху со сторонниками учения о пудгале (индивиде) в «Пудгала-винишчае» с приложением «Пудгала-винишчая» Васубандху с комментарием «Спхутартха» Яшомитры (фрагмент) // Историко-философский ежегодник. 2013. М.: КАНОН+; РООИ «Реабилитация», 2014. С. 256-276.

[14] Титлин Л.И. Васубандху. «Пудгалавинишчая». Предисловие. Пер. фрагментов 943-948 // Вестник Российского университета дружбы народов. Серия: Философия. 2016. № 4. C. $116-128$.

[15] Титлин Л.И. Васубандху. Пудгала-винишчая (Предисл., пер. фрагмента, примеч. Л.И. Титлина) // История философии. 2015. Т. 20. № 2. С. 107-125.

[16] Титлин Л.И. Проблема субъекта в индийской философии («Пудгалавнишчая» Васубандху). М.: Онтопринт, 2018.

[17] Философия буддизма: энциклопедия / отв. ред. М.Т. Степанянц; Ин-т философии РАН. М.: Вост. лит., 2011. 1050 с.

[18] Индийская философия: Энциклопедия / отв. ред. М.Т. Степанянц. М.: Восточная литература, 2009. $953 \mathrm{c}$.

\section{Для цитирования:}

Titlin L.I. The Polemics Between the Buddhists and the Vaisheshikas on the Self in "Pudgalavinishchaya" of Vasubandhu // Вестник Российского университета дружбы народов. Серия: Философия. 2019. T. 23. No 1. C. 46-55. doi: 10.22363/2313-2302-2019-23-1-46-55.

\section{For citation:}

Titlin L.I. The Polemics Between the Buddhists and the Vaisheshikas on the Self in "Pudgalavinishchaya" of Vasubandhu. RUDN Journal of Philosophy. 2019; 23 (1): 46-55. doi: 10.22363/2313-23022019-23-1-46-55.

\section{Сведения об авторе:}

Титлин Лев Игоревич - кандидат философских наук, научный сотрудник Института философии РАН (e-mail: titlus@gmail.com). 